\title{
Ashley Smith and Incarcerated Young Women: Marginalized at Any Age
}

\author{
Carla Cesaroni and Michele Peterson-Badali*
}

\begin{abstract}
Nineteen-year-old Ashley Smith died by her own hand in 2007 in a women's correctional facility in Ontario, Canada. The subject of the coroner's inquest into her death was her carceral experience and the failure of the system (leading to her death) during her time in adult federal corrections. The general focus of the inquest was on the state of federal women's corrections in Canada and the mental health issues experienced by many incarcerated women. We produced a report and provided expert testimony at the inquest regarding the need for a developmentally informed correctional framework. In this article, which is based on our inquest report and testimony, we argue that a developmental perspective is a vital lens for understanding the incarceration experience of young women.
\end{abstract}

Keywords: Ashley Smith, incarcerated young adults, adjustment, emerging adults, correctional policy

\section{Résumé}

En 2007, une jeune femme de dix-neuf ans, Ashley Smith, s'est enlevée la vie dans un établissement correctionnel pour femmes de l'Ontario, au Canada. Lenquête du coroner sur la mort de la jeune femme a soulevé l'expérience carcérale d'Ashley Smith ainsi que l'échec du système (ayant causé sa mort) durant son séjour en établissement correctionnel pour adultes. Le point culminant de l'enquête a mis en lumière l'état des centres correctionnels pour femmes au Canada et les problèmes de santé mentale que vivent de nombreuses femmes incarcérées. Dans le cadre de l'enquête du coroner, nous avons préparé un rapport et donné un témoignage d'expert concernant la nécessité d'un cadre correctionnel qui tiendrait compte du développement des détenues. Dans cet article, qui se base sur notre rapport d'enquête et notre témoignage, nous souhaitons démontrer qu'une perspective axée sur le développement est essentielle à la compréhension de l'expérience carcérale vécue par les jeunes femmes.

Mots clés : Ashley Smith, jeunes adultes en détention, ajustement, jeunes adultes, politique correctionnelle

\footnotetext{
* The authors would like to thank Lee Tustin, Richard Macklin, Irwin Elman, and Diana Cooke for their contribution to our testimony at the Coroner's Inquest into the Death of Ashley Smith and our report for the Inquest from which this article is derived.
}

Canadian Journal of Law and Society / Revue Canadienne Droit et Société, 2017, Volume 32, no. 2, pp. 249-267. doi:10.1017/cls.2017.11 


\section{Introduction}

Ashley Smith, a nineteen-year-old girl from New Brunswick, Canada, died on October 19,2007 , in a segregation cell of a women's correctional facility, having tied a ligature around her neck. Her death was reported as being the result of a number of critical failures within the Correctional Service of Canada (see Office of the Correctional Investigator 2008). The jury convened for the purpose of the Inquest into the Death of Ashley Smith was charged with answering statutory questions relating to her death and had the discretion to make recommendations aimed at the prevention of death in similar circumstances to those faced by Ms. Smith.

Smith was diagnosed as suffering from what was then known as a personality disorder (further categorized as anti-social, borderline or related diagnoses in the Diagnostic and Statistical Manual of Mental Disorders). Much of the evidence presented at the inquest focused on the delivery of mental health services in custodial settings for women and the use of secure isolation. ${ }^{1}$ In our expert testimony to the inquest we focused on the critical importance of also considering delivery of correctional services to young adults from a developmental perspective. We presented relevant research literature on psychological development during adolescence and emerging adulthood as well as the results of an environmental scan of correctional policies related to young adults in other countries. In the present paper, we summarize this work and provide an outline of the basis for a differentiated approach with respect to the incarceration of young adults - relative to adults 'in general' and the incarceration regimes in other countries that serve as reasonable comparators for Canada. We begin by reviewing facts in the case of Ashley Smith that are relevant to this paper. We then explore the literature on the coping and adjustment of incarcerated youth, followed by review and discussion of the concept of emerging adulthood and its relevance to adult correctional policy. Next, we compare and contrast Canada's current policy with respect to young adults with the correctional policies of other relevant jurisdictions. We conclude with a discussion of Ashley's Smith's difficulties while incarcerated in light of the literature on young people's adjustment to incarceration and the developmental literature on young adults.

\section{Facts in the Case of Ashley Smith Relevant to this Article}

At the age of fourteen, Ashley Smith was first charged under the Youth Criminal Justice Act (2002) with offences related to public disturbances (e.g., harassing phone calls, insulting drivers/passengers on public transportation). Over the next four years she served several sentences in secure custody at the New Brunswick Youth Centre, including her first lengthy period of incarceration, which began in December of 2003, for waving a steak knife in the street and refusing to cooperate with police while on probation. Hours after being released from the New Brunswick

A substantial body of feminist literature exists on the systemic problems associated with the management of female prisoners under the Correctional Service of Canada, particularly those with mental health issues. This formed the focus of much of the testimony presented at the inquest by other experts. Additionally, a number of articles directly related to Ashley Smith now form part of that body of work (see for example Dell, Fillmore, and Kilty 2009; Hannah-Moffat 2001, 2010; Hannah-Moffat and Klassen 2015; LeBlanc, Kilty, and Frignon 2015; Pollack 2005). 
Youth Centre for this sentence she pulled a fire alarm and was sentenced to another 75 days of secure custody. She continued to act out at the New Brunswick Youth Centre by spitting at guards, which resulted in institutional charges and days and weeks added to her sentence for each infraction; the seventy-five-day sentence turned into several months. Four days after her release she pulled another fire alarm and stole a CD, resulting in a return to secure custody. Smith was placed on continuous 'therapeutic quiet' time in the New Brunswick Youth Centre, which is a form of isolated segregation; she continued to incur numerous convictions for assaulting a peace officer and property damage. A court-ordered psychiatric assessment at Restigouche Hospital determined that she understood her behaviours and their consequences and could control her actions if she so chose; she was subsequently sentenced to another 180 days in secure custody.

Ashley Smith turned eighteen on January 29, 2006. Pursuant to section 92 of the Youth Criminal Justice Act, the New Brunswick Youth Centre made an application to the Youth Court to have Smith transferred to an adult facility, citing her needs and behaviour. Smith objected to this transfer. She was represented by counsel and swore an affidavit in support of her objection. In that affidavit, Smith stated, "Although I know that my record looks bad, I would never intentionally hurt anyone. I am really scared about the thought of going to an adult facility with dangerous people. It has occupied my mind for a long time. I have wanted to behave to ensure that I would not ever go to adult and was sure that I would succeed."

Despite her objection, the Youth Centre's application was successful and on October 5, 2006, Smith was transferred to the St. John's Correctional Centre, New Brunswick-an adult provincial facility. On October 24, 2006, Smith was convicted of institutional offences committed while in youth custody, but while she was eighteen years of age. Her sentence in aggregate was now well over two years. Despite the fact that the bulk of these charges were incurred in connection with incidents with staff while incarcerated in a youth facility, in accordance with the Youth Criminal Justice Act, her adult and youth sentences merged to form a single adult sentence. Further, the fact that the aggregate sentence exceeded two years mandated that she serve her custodial sentence in a federal (adult) facility. Ashley Smith was transferred to Nova Institution for Women in Nova Scotia on October 31, 2006. She was immediately placed in segregation due to her selfinjurious and acting out behaviour. Smith was moved sixteen times during her eleven and a half months in federal custody. In two instances, she was returned to the Grand Valley Institution for Women in Ontario the same day that she had been transferred out. A number of these transfers were involuntary and several required the involvement of the Institutional Emergency Response Team. Institutional Emergency Response teams are called in to deal with disturbances, cell extractions, and other incidents that may require the use of weapons such as batons, shields and tasers. Chemical restraints were used to ensure her compliance for at least one transfer.

All of Ashley Smith's time in federal prison was spent in administrative segregation with the exception of her stays at Philippe-Pinel Institute and St. Thomas Hospital, which are psychiatric treatment centres. However, her conditions of confinement at Philippe-Pinel Institute and St. Thomas were akin to those in 
administrative segregation. Smith resided in an empty cell, with meals provided through a food slot in her cell door. She was often not permitted to wear clothing and was instead given a security gown; she was also denied proper hygiene products, toilet paper, and books and writing materials. On occasion, she was not given menstrual products. Staff had limited meaningful interaction with Smith except when there was an incident; communication often took place through the food slot, and staff frequently used shields, batons, and spray when entering her cell.

In the next section, we outline why an understanding of the adjustment and coping of incarcerated young people is essential to contextualizing Smith's experiences in prison.

\section{Research on Coping and Adjustment amongst Incarcerated Youth}

The literature on prison adjustment overwhelmingly focuses on adult men. To date there has been little systematic research into the adjustment and experiences of young adults (those in their late teens to early twenties) in adult facilities (Lösel 2012; Midgen 2017; Steinberg et al. 2016). If there is a prison "hierarchy" of sorts, adolescent girls and young adult women are at the very bottom (Gaarder and Belknap 2004). We do know that custody ranks high amongst traumatic lifetime stressors for young people, right behind the death or divorce of parents (Frydenberg 1997; Vandergoot 2006). The interpretation of this relationship is in keeping with our assertion that incarceration exposes vulnerable individuals (in this case youth) to additional risk because of the coping mechanisms that are required to adjust to the prison environment (Cesaroni and Peterson-Badali 2005; 2010; 2013).

The aggression many youths display in custody may actually be a reflection of impaired coping (Coid et al. 2003; Kolivoski and Shook 2016; Leigey and Hodge 2013; MacKenzie 1987). However, young people differ in important ways from older adults that render them more vulnerable. Younger prisoners are less able to cope with the stress of imprisonment and experience much higher levels of anxiety as a result of having been deprived of their families and social networks (Bala and Anand, 2012; Roberts 2004; Schulman and Cauffman, 2011). The fact that they have generally been found to be involved in more disciplinary infractions, inmate-staff assaults, and conflicts with others (Gover, Perez, and Jennings 2008; Klatt et al. 2016; Kolivoski and Shook 2016; Kuanliang, Sorenson, and Cunningham 2008; Lahm 2008; Leigey and Hodge 2013; McShane and Williams 1989) compared with adult prisoners may also reflect their response to stress and difficulty coping (Coid et al. 2003; Klatt et al. 2016; Kolivoski and Shook 2016; Lahm 2008; Leigey and Hodge 2013). At least one study suggests that fighting and violence by incarcerated youth is a form of active coping utilized to reduce institutions stress (Schulman and Cauffman 2011). MacKenzie (1987) provides a number of theories regarding youth and prison adjustment. She argues that a youth's violence in prison is a young person's impulsive reaction to stress and may be a sign of immature coping ability. This may also manifest not only in striking out at others but in self-harm; for example, unlike older prisoners-whose risk of self-harm or suicide risk is often related to psychiatric illnesses-young prisoners' self-harm or suicide vulnerability can also be connected to their ability to cope with the custody environment itself (Liebling 1999). 
Evidence suggests that there is an elevated level of anxiety or stress during the initial admission period, which is reduced as the individual adjusts to the prison environment, but becomes elevated again prior to release (Backett 1987; Liebling 1999; McCorkle 1993a, 1993b; Paulus and Dzindolet 1993; Wheeler 1961; Zamble and Porporino 1990). This finding appears consistent regardless of previous prison experience. Zamble and Porporino (1990) concluded that, "repeated short stays of custody may engender at least as much pain as one long sentence, serving to exacerbate psychological vulnerabilities and emotional difficulties" $(2005,12)$. The initial stress of entry or re-entry into prison is therefore not alleviated for all of those who have served time, though some may eventually adjust more quickly than prison neophytes (Johnson 1987; Zamble and Porporino 1988). This finding holds true whether an individual enters and re-enters the same facility within the same jurisdiction, or whether an individual is transferred and must enter/re-enter a different facility in the system. For a young person entering the adult correctional system from the youth system, the stress of entry and adjustment may be particularly acute regardless of previous carceral history.

Sociologist Robert Johnson explored the concept of 'mature coping' in relation to incarcerated individuals. He argues that mature coping is defined by the ability of an offender to learn how to be an adult with some autonomy in an environment where the individual has little 'formal' power. "Mature coping means, in essence, dealing with life's problems like a responsive and responsible human being, one who seeks autonomy without violating the rights of others, security without resorting to deception or violence, and relatedness to others as the finest and fullest expression of human identity" (Johnson 2001, 83).

In contrast to this description of mature coping, prisoners who report that they cannot adapt to life in prison have difficulty regulating their thoughts and emotions (Johnson 2001, 83). Our own studies conclude that for as much as a quarter of young offenders and young adults, custody is an isolating experience in which youth spend their free time in the facility alone and far from family, feeling that staff cannot be relied upon for support or trusted; they are fearful and never fully get over the initial stress of incarceration (Cesaroni and Peterson-Badali 2010; Liebling 2003; Zamble and Porporino 1988). It is important to note that for some young people a prison sentence may mark the first time away from home of some duration (Biggam and Power 1997; Cesaroni and Bala 2008; Goldson, 2006). Research suggests that the pains "of imprisonment"-such as loss of freedom and missing family and friends-may be felt more acutely by a young person than by an adult (Cesaroni and Peterson-Badali 2005, 2010, 2013, 2016; Havey 2007; Liebling 1999). A study of the impact of visits by parents to incarcerated youth concluded that any parental visits, regardless of parental relationship quality, served to ameliorate difficulties in adjustment during incarceration (Monahan, Goldweber, and Cauffman 2011). This finding has important implications for facilities charged with the care of young persons, in which parental visits are suspended as punishment for bad behaviour by youth.

In the period of incarceration, the individual characteristics that a young person "walks into" prison with, together with characteristics of the institution itself (e.g., physical environment, staff, peers) contribute to the young person's ability to 
adjust to prison life (Cesaroni and Peterson-Badali 2010; Gover 2000; Kolivoski and Shook 2016). However, institutional characteristics become more important in predicting young people's adjustment the longer they remain in custody (Cesaroni and Peterson-Badali 2010; Gover, Perez, and Jennings 2008). For example, young people's perceptions regarding the social support that they receive in the institution becomes increasingly important over time (Cesaroni and PetersonBadali 2010). Table 1 illustrates some of the evidence from inquest documents and testimony that connects to our review of the research literature regarding the stress of, and adjustment of young people to, incarceration. In this regard, it is important to note that Ashley Smith did not act out every day of her incarceration; a summary of all incident reports involving Ashley Smith from November 1 to April 13, 2007, indicates seventy-six incidents over 164 days (Barry McGinnis, email message to Brinda Wilson-Dermuth, May 15, 2007). Instead, there was a pattern of acting out on admittance to an institution, often within hours of arrival, which reflects Smith's difficulty coping with, and adjustment to, the new custodial setting. Table 1 also provides a summary of some of the incident reports that illustrate Smith's difficulties with adjustment upon entrance to new facilities, beginning with her admission to the adult federal system for the first time.

Drawn from an internal document compiled by Correctional Services Canada, this partial sample indicates a clear pattern of acting out. This pattern of difficulty coping and adjusting to a receiving institution upon admittance did not diminish over time (i.e., with repeated admissions or transfers to facilities). Witness testimony and evidence at the inquest was consistent with our assertion that Smith had significant difficulty with adjustment, particularly at each new transfer point. Upon her first arrival at Nova Institution for Women, staff were aware that Smith was being transferred from the youth system, experienced mental health difficulties, engaged in self-harm, and had a mother to whom she planned to return upon release. However, a review of her case management plan of January 2007 suggests that management and staff applied a minimalist approach that was not sensitive to her youth, vulnerability or difficulties adjusting to carceral life (Correctional Plan 2007, 1464-70). In fact, under the heading "institution," her case management plan indicated "no specific program intervention to address this domain."

When a young person is incarcerated, the youth justice system requires that a youth worker be assigned to plan for her reintegration into the community. The assigned youth worker consults with other correctional staff and youth workers develop a reintegration plan that will maximize the young person's chances of successfully reintegrating post-incarceration. At the Inquest, we suggested that a similar approach should be taken when a young person transitions from a youth custody facility to an adult facility. Indeed, in England there is a protocol for young people who reach eighteen and must transfer to facilities in the adult system, that "has a particular focus on supporting effective assessments and information sharing, as well as promoting collaborative working" (National Offender Management Service Minister of Justice 2012, 1).

We maintain that incarcerated young people are an important sub-population within the Canadian adult prison population that have specific developmental needs regarding their ability to cope and adjust. We also argue that a developmental 


\section{Table 1}

Evidence from summary of facility incident reports related to the characterization of Ashley Smith as having difficulties with stress and adjustment to incarceration and transfers

\begin{tabular}{|c|c|c|}
\hline Facility & $\begin{array}{l}\text { Arrival Date } \\
\text { Evidence Page, Ex. } 5\end{array}$ & "Acting Out" Evidence of Adjustment Difficulties \\
\hline $\begin{array}{l}\text { Nova Institution } \\
\text { Truro, NS (first } \\
\text { adult federal) }\end{array}$ & $\begin{array}{l}\text { October } 31 / 2006 \\
\text { pp. } 61,62\end{array}$ & $\begin{array}{l}\text { 7:45 day after arrival. Ashley covered her camera, } \\
\text { said she was suicidal, ripped strips off her } \\
\text { clothing and threatened to hang herself. The IERT } \\
\text { (emergency unit) was called and she then } \\
\text { complied. She then flooded her cell by breaking } \\
\text { a sprinkler head. She was then non-compliant in } \\
\text { a shower transfer and broke a CSC telephone. }\end{array}$ \\
\hline $\begin{array}{l}\text { Regional Psychiatric } \\
\text { Centre (RPC), } \\
\text { Saskatoon, SK }\end{array}$ & $\begin{array}{l}\text { December } 20 / 2006 \\
\text { pp. } 721,754\end{array}$ & $\begin{array}{l}\text { By 9:40 am that day she had flooded her cell. } \\
\text { By 7:15 pm, she covered the camera and made } \\
\text { references to harming herself and flooding her } \\
\text { cell. By 9:35 pm she (again, apparently) flooded } \\
\text { the cell by breaking a sprinkler head. }\end{array}$ \\
\hline $\begin{array}{l}\text { L'Institue Phillipe- } \\
\text { Pinel Montreal, } \\
\text { QC }\end{array}$ & $\begin{array}{l}\text { April } 12 / 2007 \\
\text { p. } 2843\end{array}$ & $\begin{array}{l}\text { There is a record of the fact that Ashley acted out } \\
\text { to a considerable extent on the flight to PP and } \\
\text { had to be duct-taped to her plane seat. }\end{array}$ \\
\hline $\begin{array}{l}\text { Grand Valley } \\
\text { Institution (GVI) } \\
\text { Kitchener, ON }\end{array}$ & $\begin{array}{l}\text { May } 10 / 2007 \\
\text { pp. } 2987,3021\end{array}$ & $\begin{array}{l}\text { On arrival she covered the camera in her cell } \\
\text { with toilet paper. By 12:40 the next afternoon } \\
\text { she had flooded her cell again. By 1:00 she was } \\
\text { superficially cutting her forearm with a small } \\
\text { item. }\end{array}$ \\
\hline $\begin{array}{l}\text { Grand Valley Institution } \\
\text { Kitchener, Ontario }\end{array}$ & $\begin{array}{l}\text { June } 19 / 2007 \\
\text { p. } 3978\end{array}$ & $\begin{array}{l}\text { On day of return from a stay at a provincial } \\
\text { mental health facility, by 12:51 pm she had } \\
\text { tied a ligature around her neck, was observed } \\
\text { lying on the bed, her face was purple and the } \\
\text { ligature appeared tight. }\end{array}$ \\
\hline $\begin{array}{l}\text { Joliette Institution } \\
\text { Joliette, QC }\end{array}$ & $\begin{array}{l}\text { June } 27 / 2007 \\
\text { p. } 4464\end{array}$ & $\begin{array}{l}\text { By 6:15 pm night of arrival she had smeared feces } \\
\text { on her cell camera and cell window. }\end{array}$ \\
\hline $\begin{array}{l}\text { Nova Institution } \\
\text { Truro, NS }\end{array}$ & $\begin{array}{l}\text { July } 26 / 2007 \\
\text { pp. } 5000,5003\end{array}$ & $\begin{array}{l}\text { By } 3: 39 \text { that afternoon had broken the sprinkler } \\
\text { head in her cell (again). } 24 \text { hours later, she } \\
\text { became involved in a struggle with officers } \\
\text { by refusing to leave the shower. She pulled an } \\
\text { officer's shirt and had to have a wrist lock } \\
\text { applied to her. }\end{array}$ \\
\hline $\begin{array}{l}\text { Grand Valley Institution } \\
\text { Kitchener, ON }\end{array}$ & $\begin{array}{l}\text { August } 31 / 2007 \\
\text { pp. } 6119-6120 \text {; } \\
6132-6134\end{array}$ & $\begin{array}{l}\text { During the flight to GVI, Ashley was uncooperative } \\
\text { and attempted to bite and spit on staff and had } \\
\text { the spit mask placed on her. She refused to exit } \\
\text { the van on arrival and was threatened with } \\
\text { chemical spray. She then refused to comply } \\
\text { with strip-search requirements and was sprayed } \\
\text { with OC spray. }\end{array}$ \\
\hline
\end{tabular}


understanding of incarcerated young people is necessary to craft a developmentally appropriate correctional program.

\section{Development in Late Adolescence and Young Adulthood: Emerging Adulthood}

Developmental psychology research suggests that there are empirically supported justifications for the differential treatment of young people and young adults within the legal system (Shust 2014; Midgen 2017; Osgood et al. 2005; Steinberg and Schwartz 2000; Steinberg et al. 2016). It also suggests that what we know about development should be taken into account when considering legislation, policy, and practice (Shust 2014; Midgen, 2017; Osgood et al. 2005; Steinberg and Schwartz 2000; Steinberg et al. 2016). A developmental understanding of young adults is critical to understanding the differences between adults and young adults and the ways they adjust to prison.

In most western jurisdictions, where and how to draw the line between the adult and youth justice systems has been an ongoing and sometimes contentious question. The courts in fact have recognized that age is an imperfect proxy for diminished capacity (Shust, 2014). The age of eighteen is arbitrary rather than evidence-based given that cognitive functioning changes quite gradually (Farrington, Loeber, and Howell 2012; Shust 2014; Steinberg et al. 2016) and there is strong evidence that, from a neurological perspective, the human brain is not fully developed in its capacity for cognitive functioning and emotional regulation until well into young adulthood (Justice Committee, House of Commons, Canada 2016; Midgen 2017; Prior et al. 2011). Research suggests that brain development continues long after the age of eighteen, and is not likely fully mature until age twentyfive (Kramers-Olen 2015). In Roper versus Simmons, (which ultimately concluded that the death penalty was unconstitutional for juveniles in the United States) the majority recognized the psychological, neuro-scientific explanations for youthfulness and noted that "the qualities that distinguish juveniles form adults do not disappear at 18" (Shust 2014, 685).

From a psychological perspective, evidence shows that psychosocial capacities and moral reasoning abilities vary considerably between individuals so that some remain immature longer than others, including after the legal age of adulthood (Justice Committee House of Commons, 2016; Prior et al. 2011; Steinberg et al. 2016). As a group, young adult offenders are more similar to adolescents than to adults with respect to features such as executive functioning, impulse control, malleability, responsibility, susceptibility to peer influence, and competence (Farrington, Loeber, and Howell 2012, 741). Certainly, they do not reach all the attributes associated with our conceptions of "adulthood" by age eighteen (Farrington, Loeber, and Howell 2012; Justice Committee House of Commons 2016; Kramers-Olen 2015; Midgen 2017; Steinberg et. al 2016). Indeed, age is not a reliable marker of maturity in most young people, but in particular for those in conflict with the law (Shust 2014; Kramers-Olen 2015; Midgen 2017; Vandergoot 2006). In fact, developmental psychologists now recognize the age from late teens to mid-twenties as a distinct developmental stage, distinguishable from both adolescence and adulthood. 
Scholarly attention to this developmental period has increased tremendously in recent years and it is now widely referred to as "emerging adulthood," a phrase first coined by psychologist Jeffrey Arnett (2000). Arnett argues that individuals in the eighteen to twenty-four year age range constitute a developmentally distinct sub-group of the adult population. Additionally, he maintains that it is a critical period-biologically, socially, and legally-for the transition into adulthood. Emerging adults struggle if they are part of especially vulnerable populations such as those aging out of foster care, coming out of the criminal justice system, or experiencing disabilities (Osgood et al. 2005). Though the transition to adulthood cannot be separated from what has happened earlier in a young person's life, it is an important life stage with its own critical avenue of influence for young adults (Altschuler 2005; Shust 2014; Midgen 2017; Steinberg et al. 2016). Gaining acceptance of emerging adulthood as a developmental concept is similar to efforts a century ago, when psychologists made the case that adolescence was a new developmental stage (Midgen 2017).

Criminologists have argued that the need to treat emerging adults differently than adults is especially important if a psychological evaluation reveals a 'youthful' personality in terms of intelligence and emotional maturity (Albrecht 2004; Justice Committee House of Commons 2016; Shust 2014; Prior et al. 2011). Indeed, research suggests that youthful offenders (whether adolescent or young adult) tend to be developmentally less mature than their non-offending peers (see Steinberg, Chung, and Little 2004; Monahan et al. 2009; Vandergoot 2006). As a result, it has been suggested that "[b]ecause transitional periods have been prolonged and entrance into the adult world more difficult, failure to respect the differences between young adults and adults risks failure of adequate justice for young adult offenders" (Albrecht 2004, 474).

\section{Emerging Adulthood and Youth vs. Adult Custody Systems}

Differences in philosophy that characterize youth and adult justice systems have generally meant that youth and adult custody facilities have very different organizational climates (Bishop and Frazier 2000; Kovoliski and Shook 2016; Lane et al. 2002). Adult facilities in many western jurisdictions tend to be focused on security and order through various demonstrations of correctional power. In contrast, juvenile facilities focus more on rehabilitation, offer a kinder tone and a more supportive environment, and have staff that care about youth, are able to provide guidance, and are skilled at modeling and teaching appropriate behaviour (Inderbitzin 2007; Kolivoski and Shook 2016). This delicate balance between control and flexibility that is required for successful rehabilitation or treatment in secure facilities is one of the main factors that shape institutional climate (van der Helm, Stams, and van der Laan 2011).

Youth with impulsive traits and interpersonal skills deficits may present as defiant, manipulative, and uncaring when confronted by authority figures, particularly in stressful situations (Vandergoot 2006, 57). This is in part because they lack the social skills and maturity necessary to deal with confrontational situations (Vandergoot 2006, 57). Further, the manner in which frontline staff relate to prisoners may impact their well-being and psychological health. As noted previously, young 
people have more disciplinary problems than adults and adult facilities have a different culture and climate that is more enforcement and authority-oriented (rather than focusing on supportive relationships). Together, these facts suggest that young adults are particularly disadvantaged in an adult-oriented, authoritarian type of facility; those features we have delineated previously come together to heighten the negative impacts of prison on young people (see Figure 1).

A study of youth who had done time in both young offender and adult facilities concluded that when the youth justice system had an effect, it was positive: youth gained skills and had hope. In contrast, when the adult system had an effect, it was negative: youth lost the connection to family members and community, feelings of safety, and environments where they were treated with respect (Lane et al. 2002). In terms of differences in coping in adult versus juvenile facilities, a study comparing suicide rates noted that young people's odds of committing suicide were 36 times greater in an adult jail than in a juvenile facility (Austin, Johnson, and Gregoriou 2000). Research also suggests that in addition to increasing the risk of suicide, incarcerating young people in adult facilities increases the risk of depression and post-traumatic stress disorder (PTSD) (Birckhead 2015; Ng et al. 2011). Interviews with frontline staff and probation officers who deal with both young people and adults revealed that young people are viewed as needier and more likely to crave contact with staff (Crawley 2006). Interviews with officers in a

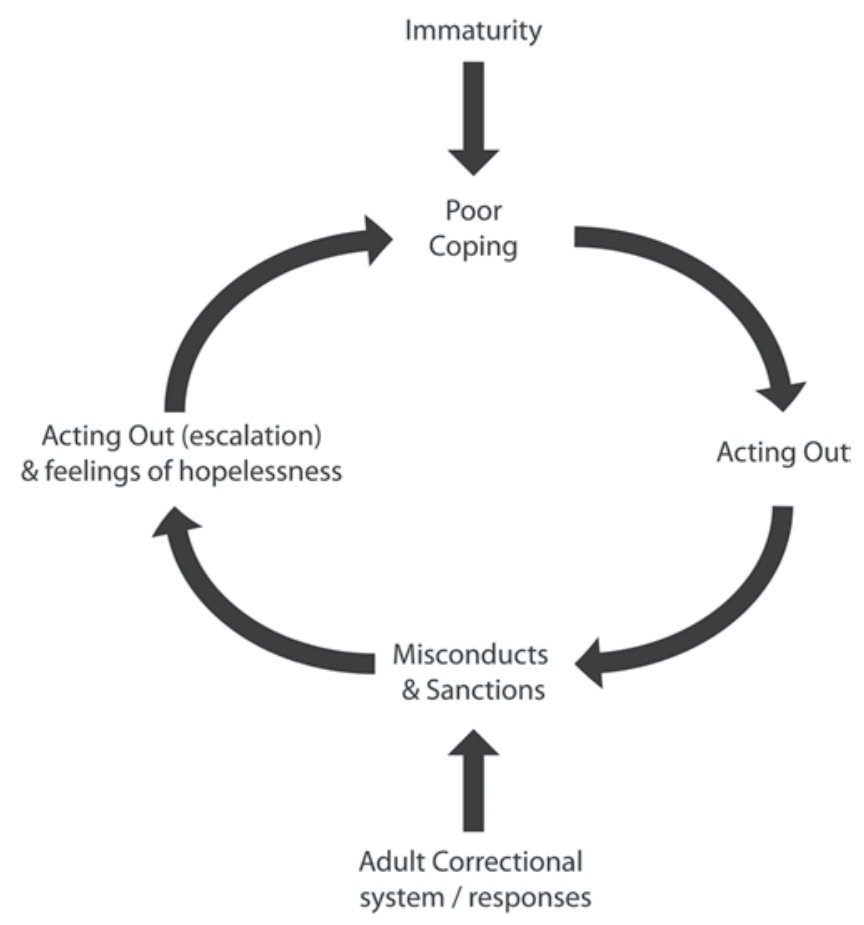

Figure 1 Negative cycle of poor coping and distressed and acting out behaviour in young people incarcerated in adult-oriented custody settings. 
women's prison in the United States demonstrated that officers receive little training on how to deal with young women and that officers often express frustration when assigned to work on the under-twenty-one unit (Gaarder and Belknap 2004). Some authors suggest that a general lack of understanding of young women in custody may explain the reluctance of staff to work with girls and young women because of a perception that they are too complex and demanding (Cernkovich, Lanctôt, and Giordano 2008).

Taken together, the evidence from developmental psychology and the criminological and sociological literature suggests that young adults constitute a distinct sub-group of the adult prison population who need the kind of institutional climate that characterizes the youth system. The following section reviews how this issue has been addressed in other jurisdictions.

\section{Young Adults in Other Jurisdictions}

How to deal with young adult offenders is currently one of the most important areas of juvenile justice reform in Europe (Dünkel and Pruin 2012). In England and Wales, concern over the legal treatment of young adults led to the formation of the Barrow Cadbury Trust's Transition to Adulthood (T2A) initiative, which advocates for the recognition of the specific needs of young adults within the criminal justice system, including sentencing. This group, along with a prominent group of criminologists in the United States and United Kingdom, have made the issue of young adults the focus of policy recommendations and calls for legislative change. In a report for T2A, David Prior of the University of Birmingham and his colleagues had the following to say: "Overall, the research reviewed points emphatically to the inappropriateness of an arbitrary age limit as the key factor determining the kind of judicial response an offender should receive, and that in the young adult group, the level of maturity exhibited by an offender is a valid factor to be considered within the legal process. There are, moreover, indications that this conclusion is becoming accepted in a growing number of national jurisdictions, albeit to varying degrees" (Prior et al. 2011, 35).

The United Nations defines 'youth' in terms of the age span from fifteen to twenty-four years. The 2003 Council of Europe recommended that young adult offenders under age twenty-one be treated in a manner comparable with juveniles when the judge is of the opinion that they are not as mature or responsible for their actions as full adults (Dünkel and Pruin 2012). In 2004, the International Association of Penal Law passed a final resolution stating that the special provisions for juveniles should be extended to the age of twenty-five (Dünkel and Pruin 2012).

The criminal laws of most European countries provide for special arrangements to be made when dealing with young adults in either criminal or juvenile law (Dünkel and Pruin 2012). Offenders age eighteen to tweny are dealt with differently than older adults in Scandinavia and 18 other European countries (including Austria, Germany, and The Netherlands) (Farrington, Loeber, and Howell 2012). In Germany, juvenile law is applied to a young adult if, at the time of the offence, "the youth's moral and psychological development was like a juvenile" and "the offence was similar to a typical juvenile crime” (Dünkel and Pruin 2012, 21). 
As is the case in Canada, in England, Wales, and Scotland the legal treatment of youth changes at eighteen. However, unlike in Canada, young adults are treated differently from older adults ${ }^{2}$, with special provisions in Britain for adult-sentenced "young offenders" (a term that describes individuals aged eighteen to twenty) (Farrington, Loeber, and Howell 2012). In particular, these offenders are not sent to prison but to young offender institutions or youth-specific ranges within adult facilities. For example, the Scottish Prison Service must house those aged over sixteen but under twenty-one in dedicated Young Offender Institutions or separate wings of adult facilities regardless of their numbers (James Carney, e-mail message to Author, September 18,2013$)^{3}$. Young adults in Scotland are required to transfer to an adult prison at the age of twenty-one. However, provision can be made in certain circumstances for a young offender to remain in a young offender institution beyond the age of twenty-one but not beyond their twenty-third birthday. The Scottish Prison Service's Legal Policy branch is currently considering amending this age cut-off to an older age point when there are demonstrable signs of vulnerability in a prisoner (James Carney, e-mail message to Author, September 18, 2013).

In the United States, Florida, Virginia, and Pennsylvania have separate correctional facilities for young adult offenders. In most states a juvenile court may have jurisdictional control until a young person is twenty-one and the California Department of Juvenile Justice continues to have jurisdiction over juveniles until their twenty-fifth birthday (Farrington, Loeber, and Howell 2012).

New York State recently moved to separate eighteen to twenty-one year olds from the general prison population and Connecticut proposed a new initiative to dedicate one of its eighteen facilities for eighteen to twenty-four year olds.

\section{Canada's Current Policy on Young Adults}

Roughly fifteen percent of the current federal prisoner population in Canada is under the age of twenty-five; for women the proportion is almost twenty percent (Office of the Correctional Investigator 2013). Many justifications for the special treatment of young people that underpin the Youth Criminal Justice Act also apply to young adult offenders (Farrington, Loeber, and Howell 2012). Taken together, our studies on adolescents and young adults suggest that for at least ten to twentyfive percent of youth, custody can be a painful experience (Cesaroni and PetersonBadali 2005, 2010, 2013, 2016). Our work supports conclusions from previous studies that found that custody can be harmful to the emotional and psychological integrity of young people (see Goldson 2006). The research reviewed in this article suggests that at least for vulnerable young adults, prison may be equally damaging to young adults as custody is to adolescents.

2 In England, Scotland, and Wales youth 17 and under are termed 'juveniles'-the equivalent of Canada's 'young person' (formerly 'young offender'). In England, Scotland, and Wales, youth 18-20 years of age, inclusive, are called 'young offenders'.

3 In accordance with the terms of United Nations Convention on the Rights of the Child, 16-17-yearold youth must be held in separate accommodation from 18-20 year olds in Her Majesty's Young Offender Institutions, although daytime association is permissible; James Carney, personal communication [email], September 18, 2013 
The 2005-2006 and 2013-2014 Annual Reports from Canada's Office of the Correctional Investigator (OCI) are consistent with many of the assertions we have made in this article. The OCI noted that the Correctional Service of Canada does not meet the special service and program needs of prisoners aged twenty and younger, who very often find themselves in disadvantaged situations, including segregation, abuse by other prisoners, limited access to or success in programming, gang affiliations, and delayed conditional release. The OCI found that the Correctional Service of Canada does not provide special housing, programming or other services for younger adult offenders. In the 2013-2104 report (p. 41) the Correctional Investigator recommended that "the Correctional Service develop and implement a National Strategy for Younger Offenders in collaboration with external stakeholders with expertise in service delivery to young adults. The Strategy should address the need for policies, programs and services tailored specifically to meet the unique needs of offenders aged 25 and under." This recommendation has not been implemented to date, although the Commissioner of Corrections Canada publically endorsed it at the Ashley Smith Inquest (see cross examination by Macklin, October 16, 2013).

It is our view that the implementation of new policies, programs, and services to meet the unique needs of young adult offenders cannot simply be accommodated through trivial modifications to the existing adult correctional regime. Young adult offenders require distinct policies, programs, and services that are in keeping with their developmental maturity and needs. As noted above, in other jurisdictions this includes separate accommodation. More importantly, there needs to be dedicated staff for young adult units, who are trained in the developmental issues and needs of young adults so as to recognize and respond to the particular issues faced by a young adult housed in an adult prison. Ideally, staff would have prior experience working in youth facilities and would be accustomed to nonconfrontational behaviour management methods that rely less on use of force techniques and more on peaceful conflict resolution (Austin, Johnson, and Gregoriou 2000). The use of force, cell extractions, physical and chemical restraints, and special response teams that are used in adult facilities are often considered to be inappropriate for anyone, but are particularly inappropriate for women and young adults (Austin, Johnson, and Gregoriou 2000).

As we have outlined previously, a key focus of this article is the developmental context within which Ashley Smith's difficulties-and ultimately her death-need to be considered. In this regard, it is important to note that our position regarding the importance of substantively different care and treatment of incarcerated young adult offenders in multiple aspects of their day-to-day experience (including, but not limited to, treatment of mental health issues) is consistent with current mental health policy and practice. For example, in Ontario, the need for support as youth transition from adolescent-based services to adult-focused services was highlighted in Open Minds, Healthy Minds: Ontario's Comprehensive Mental Health and Addictions Strategy (Government of Ontario 2011). This strategy is being implemented through a ten-year plan that involves building eighteen Service Collaborative Centres across Ontario that are "focused on improving services for children and youth in transition: from community to hospital settings; between health and justice systems; and from child-focused to adult services" (emphasis added) (Canadian Mental Health 
Association 2016). Many of these collaborations are developing and evaluating specific initiatives to address the youth-adult transition and evidence is emerging that providing developmentally appropriate, transition-specific services can improve outcomes for youth with mental health concerns (Joanna Henderson, e-mail to Author, October 29, 2013).

\section{Ashley Smith's Difficulties in the Context of the Literature on Adjustment to Incarceration and Young Adult Development}

There are a number of inquest documents and testimonies that connect to the above review of research and practice regarding emerging/young adults in custody facilities. Ashley Smith's lack of maturity, childlike qualities and behaviour, and the difficulties she experienced with adjustment to incarceration were perceived as stemming from the lack of fit between her developmental status and her incarceration environment. A number of inquest witnesses, who were diverse in terms of their backgrounds, occupations, and roles in Smith's care, testified or reported on her immaturity and the difficulties and vulnerabilities associated with it. They described her as "child-like," "immature," "like a kid in an adult body," as acting "several years younger than her age."

Aside from staff observations that Smith resembled a child more than an adult, inquest documents and testimony note the following interconnected concerns: that her immaturity made her more vulnerable psychologically; that the length of time she spent in custody in general and in segregation in particular prevented her from typical development; that she did not have age-appropriate peers with whom to interact and connect; that custody harmed her because she was immature and vulnerable; and that she did not receive developmentally-appropriate services in the adult system. Moreover, there was evidence presented that her age, lack of mental capacity, and vulnerability made her afraid of mixing with adults in the general population because she was already not coping well and was afraid of her ability to manage socializing with the other, adult prisoners.

It is telling that the proportion of time Smith spent in segregation compared to that she spent in the general population in the youth system was roughly two to one (Sapers 2008) while in the adult prison system it was ninety-nine to one, where she was only outside of segregation for two days in September 2007. Inquest evidence (2013) from the Acting Warden of Grand Valley Institution indicated that she was warned by the previous warden that Smith tried to sabotage her chances of being moved the last time she was considered for a move from segregation to the general population; the previous warden appeared to link Smith's acting out with her fear of interacting with the other women. In our own studies on incarcerated youth (including those in the eighteen to twenty-four age range), we ask how "important" certain conditions of confinement are. Overwhelmingly, and regardless of age, they rate "being separated from adult offenders" as "important" or "very important."

In addition, testimony from the inquest suggests that the "mixing" of young women with older adult woman can cause management problems because of the dysfunctional and problematic relationships that can develop between older women and young women who are immature-whether because of older women 
wanting to act as "mothers" or seeking younger partners while incarcerated (Dr. Renee Fugere, cross-examination testimony by Neil Wilson, April 23, 2013). This assertion is supported by academic research (Gaarder and Belknap 2004). It is important to recognize that even in relation to their adult female counterparts, young women are significantly more marginalized and vulnerable. Amongst all correctional populations, adolescent girls and young adult women are truly the "forgotten few."

\section{Conclusion}

Research indicates that incarceration is a difficult, stressful, and challenging event for many individuals, but it is especially traumatic for the most vulnerable, particularly the young. Evidence suggests that for Ashley Smith incarceration was such an event-one that led to a cascade of difficulties in coping that had multiple and interacting negative impacts that ultimately contributed to her death in custody. Additionally, we argue that her time in segregation exacerbated her coping and adjustment vulnerabilities. Our recommendations to the jury at the Ashley Smith inquest were based upon the research literature on the adjustment of individuals to incarceration, the emerging research on incarcerated young adults, and our own research. Our assertion is that those recommendations are preventive measures that would help to ensure that young adults are supported while incarcerated in a way that befits their developmental stage and particular vulnerabilities. The jury verdict and recommendations (Office of the Chief Coroner 2013,12 ) took up many of our own recommendations regarding young adults, including (recommendation \# 85): "That CSC establish separate and distinct policies for young adults, that is, 18-21 year olds, within adult institutions which will be geared toward their cultural and developmental needs (e.g. educational, vocational, therapeutic, as appropriate to specific needs and situations).”

Unfortunately, Canada remains considerably out-of-step with other Western democracies regarding preventive measures aimed at the young adult offender population within adult correctional facilities. It is our view that it is time for that gap to be closed.

\section{References}

Albrecht, Hans-Jörg. 2004. Youth justice in Germany. In Youth Crime and Youth Justice: Comparative and Cross National Perspectives, ed. Michael Tonry and Anthony N. Doob, 443-93. Chicago: University of Chicago Press.

Altschuler, David. 2005. Policy and program perspectives on the transition to adulthood for adolescents in the juvenile justice system. In On Your Own Without a Net: The Transition to Adulthood for Vulnerable Populations, ed. Wayne Osgood, E. Michael Foster, Constance Flanagan, and Gretchen R. Ruth, 92-113. Chicago: University of Chicago Press.

Arnett, Jeffrey J. 2000. Emerging adulthood: A theory of development from the late teens through the twenties. American Psychologist 55 (5): 469-80.

Austin, James, Kelly Dedel Johnson, and Maria Gregoriou. 2000. Juveniles in Adult Prisons and Jails: A National Assessment (p. 4). Washington, DC: BJA Bureau of Justice Assistance, Institute on Crime, Justice and Corrections at the George Washington University and National Council on Crime and Delinquency.

Backett, S. A. 1987. Suicide in Scottish prisons. British Journal of Psychiatry 151 (2): 218-21. 
Bala, Nicholas, and Sanjeev Anand. 2012. Youth Criminal Justice Law. Toronto: Irwin Law. Biggam, Fiona H., and Kevin G. Power. 1997. Social support and psychological distress in a group of incarcerated young offenders. International Journal of Offender Therapy and Comparative Criminology 41: 213-30.

Birkchead, Tamar R. 2015. Children in isolation: The solitary confinement of youth. Wake Forest Law Review 50 (1): 1-67.

Bishop, Donna, and Charles Frazier. 2000. Consequences of transfer. In The changing borders of juvenile justice: Transfer of adolescents to the criminal court, ed. Jeffrey Fagan and Frank E. Zimring, 227-76. Chicago: University of Chicago Press.

Canadian Mental Health Association. 2016 The Strategy. System Improvement through Service Collaboratives. http://servicecollaboratives.ca/strategy/

Cernkovich, Stephen A., Nadine Lanctôt, and Peggy C. Giordano. 2008. Predicting adolescent and adult antisocial behavior among adjudicated delinquent females. Crime \& Delinquency 54 (1): 3-33.

Cesaroni, Carla, and Nicholas Bala. 2008. Deterrence as a principle of youth sentencing: No effect on youth but a significant effect on judges. Queens Law Journal 34: 447-81.

Cesaroni, Carla, and Michele Peterson-Badali. 2005. Young offenders in custody: Risk and adjustment. Criminal Justice and Behavior 32 (3): 251-77.

-2010. Understanding the adjustment of incarcerated young offenders: A Canadian example. Youth Justice 10 (2): 1-19.

- 2013. The importance of institutional culture to incarcerated youth and young adults. Candian Journal of Criminology and Criminal Justice 54 (4): 563-76.

2016. The role of fairness in the adjustment of adolescent boys to pre-trial detention. The Prison Journal 96 (4): 1-20.

Coid, Jeremy, Ann Petruckevitch, Paul Bebbington, Rachel Jenkins, Traolach Brugha, Glyn Lewis, Michael Farrell, and Nichola Singleton. 2003. Psychiatric morbidity in prisoners and solidary confinement: Disciplinary segregation. The Journal of Forensic Psychiatric and Psychology 14 (2): 298-319.

Crawley, Elaine. 2006. Doing prison work: The public and private lives of prison officers. In Prison Readings, ed. Yvonne Jewkes and Helen Johnston, 209-21. Portland, OR: Willan Publishing.

Dell, Colleen Ann, Catherine J. Filmore, and Jennifer M. Kilty. 2009. Looking back 10 years after the Arbour inquiry. The Prison Journal 89 (3): 286-308.

Dünkel, Frieder, and Ineke Pruin. 2012. Young adult offenders in juvenile and criminal justice systems in Europe. In Young Adult Offenders: Lost in Transition, ed. Friedrich Lösel, Anthony Bottoms, and David P. Farrington, 11-38. New York, NY: Routledge.

Farrington, David P., Rolf Loeber, and James C. Howell. 2012. Young adult offenders: The need for more effective legislative options and justice processing. Criminology \& Public Policy 11 (4): 729-50.

Frydenberg, Erica. 1997. Adolescent coping: Theoretical and research perspectives. New York, NY: Routledge.

Gaarder, Emily, and Joanne Belknap. 2004. Little women: Girls in adult prison. Women \& Criminal Justice 15 (2): 51-80.

Goldson, Barry. 2006. Damage, harm and death in child prisons in England and Wales: Questions of abuse and accountability. The Howard Journal of Criminal Justice 45 (5): 449-67.

Gover, Angela R. 2000. Influence of child maltreatment on juveniles' psychological adjustment within correctional institutions. PhD diss., University of Maryland.

Gover, Angela R., Deanna M. Perez, and Wesley G. Jennings. 2008. Gender differences in factors contributing to institutional misconduct. The Prison Journal 88 (3): 378-403. 
Government of Ontario. 2011. Open Minds, Healthy Minds: Ontario's Comprehensive Mental Health and Addictions Strategy. http://www.health.gov.on.ca/en/common/ministry/ publications/reports/mental_health2011/mentalhealth_rep2011.pdf

Hannah Moffat, Kelley. 2001. Punishing Exception. Penal Governance and Federal Imprisonment of Women in Canada. Toronto: University of Toronto Press.

Hannah-Moffat, Kelley. 2010. Sacrosanct or flawed: Risk accountability and gender-responsive penal politics. Current Issues in Criminal Justice 22 (2): 195-215.

Hannah-Moffat, Kelley, and Amy Klassen. 2015. Normalizing exceptions: Solitary confinement and the micro-politics of risk/need in Canada. In Extreme Punishment: Comparative Studies in Detention, Incarceration and Solitary Confinement, ed. Keramet Reiter and Alexa Koening, 135-56. New York: St Martins Press.

Harvey, Joel. 2007. Young men in prison: Surviving and adaptation to life inside. Portland: Willan Publishing.

Inderbitzin, Michelle. 2007. A look from the inside: Balancing custody and treatment in a juvenile maximum-security facility. International Journal of Offender Therapy and Comparative Criminology 51 (3): 348-62.

Johnson, Robert. 1987. Hard time: Understanding and Reforming the Prison. Monterey: Brooks/Cole Publishing.

- 2001. Hard time: Understanding and Reforming the Prison Wadsworth. Belmont: Wadsworth Publishing Company.

Justice Committee House of Commons. 2016. The Treatment of Young Adults in the Criminal Justice System. London: House of Parliament.

Klatt, Thimna, Stephan Hagl, Marie C. Bergmann, and Dirk Baier. 2016. Violence in youth custody: Risk factors of violent misconduct amongst inmates of German young offender institutions. European Journal of Criminology 13 (6): 727-43.

Kolivoski, Karen M., and Jeffrey J. Shook. 2016. Incarcerating juveniles in adult prisons. Criminal Justice and Behaviour 43 (9): 1242-59.

Kramers-Olen, Anne L. 2015. Neuroscience, moral development, criminal capacity and the Child Justice Act: justice or injustice? South African Journal of Psychology 45 (4): 466-79.

Kuanliang, Attapol, Jon R. Sorensen, and Mark D. Cunningham. 2008. Juvenile inmates in an adult prison system rates of disciplinary misconduct and violence. Criminal Justice and Behavior 35 (9): 1186-1201.

Lahm, Karen F. Inmate-on-inmate assault: A multilevel examination of prison violence. Criminal Justice and Behavior 35 (120): 120-37.

Lane, Jodi, Lonn Lanza-Kaduce, Charles E. Frazier, and Donna M. Bishop. 2002. Adult versus juvenile sanctions: Voices of incarcerated youths. Crime \& Delinquency 48 (3): 431-55.

LeBlanc, Nicole, Jennifer M. Kilty, and Sylvie Frignon. 2015. Examining the preventable but predictable death of Ashley Smith. International Journal of Prisoner Health 11 (3): 126-40.

Leigey, Margaret E., and Jessica P. Hodge. And then they behaved: Examining the institutional misconduct of adult inmates who were incarcerated as Juveniles. The Prison Journal 93 (3): 272-90.

Liebling, Alison. 1999. Prison suicide and prison coping. In Prisons, ed. Michael Tonry and Joan Petersilia, 283-360. Chicago: University of Chicago Press.

—. November, 2003. Legitimacy, Prison Suicide and the Moral Performance of Prisons. Paper Presented at the Annual Meeting of The American Society of Criminology, Chicago.

Lösel, Friedrich. 2012. What works in correctional treatment and rehabilitation for young adults? In Young Adult Offenders: Lost in Transition, ed. Friedrich Lösel, Anthony Bottoms, and David P. Farrington, 74-112. New York: Routledge. 
MacKenzie, Doris L. 1987. Age and adjustment in prison: Interactions with attitudes and anxiety. Criminal Justice and Behavior 14 (4): 427-47.

McCorkle, Richard C. 1993a. Fear of victimization and symptoms of psychopathology among prison inmates. Journal of Offender Rehabilitation 19 (1-2): 27-42.

-1993b. Living on the edge: Fear in a maximum security prison. Journal of Offender Rehabilitation 20 (1-2): 73-91.

McShane, Marilyn D., and Frank P. Williams III. 1989. The prison adjustment of juvenile offenders. Crime and Delinquency 35 (2): 254-69.

Midgen, Scott E. 2017. The injustice of a felony conviction for offenders under age twentyone: A new option for the courts to save our youths' futures. Family Court Review 55 (2): 292-306.

National Offender Management Service, Ministry of Justice, HM Prison Service. 24 September 2012. The Transition Process: Guidance on transfers from under 18 Young Offender Institutions to young adult Young Offender Institutions.

Monahan, Kathryn C., Laurence Steinberg, Elizabeth Cauffman, and Edward P. Mulvey. 2009. Trajectories of antisocial behavior and psychosocial maturity from adolescence to young adulthood. Developmental Psychology 45 (6): 1654-68.

Monahan, Kathryn C., Asha Goldweber, and Elizabeth Cauffman. 2011. The effects of visitation on incarcerated juvenile offenders: How contact with the outside impacts adjustment on the inside. Law and Human Behavior 35 (2): 143-51.

Ng, Irene Y., Xiaoyi Shen, Helen Sim, Rosemary C. Sarri, Elizabeth Stoffregen, and Jeffrey J. Shook. 2011. Incarcerating juveniles in adult prisons as a factor in depression. Criminal Behaviour and Mental Health 21 (1): 21-34.

Office of the Correctional Investigator. 2013. Correctional Service Canada Data: Federal Inmates Under 25. Ottawa: Government of Canada.

— 2008 A Preventable Death, by Howard Sapers. Ottawa: Government of Canada. http://www.oci-bec.gc.ca/cnt/rpt/oth-aut/oth-aut20080620-eng.aspx.

Osgood, D. Wayne, E. Michael Foster, Constance Flanagan, and Gretchen R. Ruth. 2005. Programs and Policy Goals for Helping Vulnerable Youth as They Move into Adulthood. Philadelphia: University of Pennsylvania.

Paulus, Paul B., and Mary T. Dzindolet. 1993. Reactions of male and female inmates to prison confinement. Criminal Justice and Behavior 20 (2): 149-66.

Pollack, Shoshana. 2005. Taming the shrew: Regulating prisoners through women-centered mental health programming. Critical Criminology 13: 71-87.

Prior, David, Kathryn Farrow, Nathan Hughes, Gill Kelly, Gary Manders, Sue White, and Bernadette Wilkinson. 2011. Maturity, Young Adults and Criminal Justice: A Literature Review. Birmingham: University of Birmingham.

Roberts, Julian V. 2004. Harmonizing the sentencing of young and adult offenders: A comparison of the Youth Criminal Justice Act and Part XXIII of the Criminal Code. Canadian Journal of Criminology and Criminal Justice. 46 (3): 301-26.

Sapers, H. 2008. A preventable death: The Ashley Smith report. New Brunswick: Ombudsman and Child and Youth Advocate.

Schulman, Elizabeth P., and Elizabeth Cauffman. 2011. Coping while incarcerated: A study of male juvenile offenders. Journal of Research on Adolescence 21 (4): 818-26.

Shust, Kelsey B. 2014. Extending sentencing mitigation for deserving young adults. The Journal of Criminal Law \& Criminology 104 (3): 668-704.

Steinberg, Laurence, and Robert G. Schwartz. 2000. Developmental psychology goes to court. In Youth on Trial: A Developmental Perspective on Juvenile Justice, ed. Thomas Grisso and Robert G. Schwartz, 9-31. Chicago: University of Chicago Press. 
Steinberg, Laurence, He Len Chung, and Michelle Little. 2004. Reentry of young offenders from the justice system a developmental perspective. Youth Violence and Juvenile Justice 2 (1): 21-38.

Steinberg, Laurence, Thomas Grisso, Elizabeth S. Scott, and Richard J. Bonnie. 2016. Don't treat young adults as teenagers. New York Times, 29 April.

van der Helm, Peer, Geert Jan Stams, and Peter van der Laan. 2011. Measuring group climate in prison. The Prison Journal 91 (2): 158-76.

Vandergoot, Mary E. 2006. Justice for Young Offenders: Their Needs, Our Responses. Saskatoon: Purich Publishing Ltd.

Wheeler, Stanton. 1961. Socialization in correctional communities. American Sociological Review 26: 697-712.

Zamble, Edward, and Frank J. Porporino. 1988. Coping, Behavior and Adjustment in Prison Inmates. New York: Springer-Verlag.

- 1990. Coping, imprisonment and rehabilitation: Some data and their implications. Criminal Justice and Behavior 17: 53-70.

Carla Cesaroni

Associate Professor

University of Ontario Institute of Technology

carla.cesaroni@uoit.ca

Michele Peterson-Badali

Associate Professor

Ontario Institute for Studies in Education

University of Toronto

m.petersonbadali@utoronto.ca 